\title{
Derim öncesi putresin uygulamasının 0900 Ziraat kiraz çeşidinin meyve kalitesi üzerine etkileri
}

\author{
Derya ERBAȘ ${ }^{1}$, Mehmet Ali KOYUNCU ${ }^{1}$, Funda ÖZÜSOY' ${ }^{1}$, Cemile Ebru ONURSAL ${ }^{2}$
}

${ }^{1}$ Isparta Uygulamalı Bilimler Üniversitesi, Tarım Bilimleri ve Teknolojileri Fakültesi, Bahçe Bitkileri Bölümü, ISPARTA

2Batı Akdeniz Tarımsal Araştırma Enstitüsü Müdürlüğü, ANTALYA

Alınış tarihi: 24 Temmuz 2018, Kabul tarihi: 22 Eylül 2018

Sorumlu yazar: Mehmet Ali KOYUNCU, e-posta:koyuncu.ma@gmail.com

\section{Öz}

Çalışmada, derim öncesi putresin uygulamasının 0900 Ziraat kiraz çeşidinin meyve kalitesi üzerine etkileri araştırılmıştır. Derim öncesi uygulamaları için ağaçlara sprey şeklinde tahmini ticari derim tarihinden 3 hafta önce $0,2.5$, 5 ve 7.5 mM dozlarında putresin (PUT)+\%0.01 oranında yayıcı yapıştırıcı (Tween-20) ilave edilerek yapılmıştır. Kontrol ağaçlarına ise sadece saf su+yayıcı yapıștırıcı uygulanmıştır. Optimum derim tarihinde toplanan meyvelerde, derimden hemen sonra, meyve ağırlığı (g), meyve eti ağırlığı (g), çekirdek ağırlığı (g), meyve eni $(\mathrm{mm})$, meyve boyu $(\mathrm{mm})$, meyve eti sertliği $(\mathrm{N})$, meyve kabuk rengi $\left(\mathrm{L}^{*}, \mathrm{a}^{*}, \mathrm{~b}^{*}, \mathrm{C}^{*}, \mathrm{~h}^{\circ}\right)$, titre edilebilir asitlik miktarı (mg.mL ${ }^{-1}$ ), suda çözünür kuru madde miktarı (\%), ve solunum hızı (mL.CO $\left.2 . \mathrm{kg}^{-1} \mathrm{~s}^{-1}\right)$ ölçümleri ile duyusal analizler yapılmıştır. Putresin uygulamalarının tüm dozları kontrole göre daha iyi sonuçlar vermiştir. Genellikle $2.5 \mathrm{mM}$ ve $5 \mathrm{mM}$ putresin dozları meyve ağırlığı, meyve eti sertliği, kroma, hue ve titre edilebilir asitlik değerlerini daha olumlu etkilemiştir. Sonuç olarak, derim öncesi $2.5 \mathrm{mM}$ putresin uygulamasının, kirazlarda derim döneminde meyve kalitesinin iyileştirilmesi için kullanılabileceğ söylenebilir.

Anahtar kelimeler: Poliaminler, kalite, Prunus avium L., derim öncesi uygulama

\section{Effects of pre-harvest putrescine treatment on fruit quality of sweet cherry cv. 0900 Ziraat}

\footnotetext{
Abstract

This research was carried out to determine the effect of pre-harvest putrescine treatment on the fruit
}

harvest quality of sweet cherry cv. 0900 Ziraat. Different doses $(2.5,5$ and $7.5 \mathrm{mM})$ of putrescine (PUT), and Tween-20 (0.01\%) (as a surfactant) were sprayed on sweet cherry trees as well as distilled water with Tween-20 (control group) 3 weeks before commercial harvest. Sweet cherry fruit were harvested at optimal harvest maturity. Fruit weight (g), fruit width $(\mathrm{mm})$, fruit length $(\mathrm{mm})$, kernel weight $(\mathrm{g})$, fruit flesh weight $(\mathrm{g})$, fruit flesh firmness $(\mathrm{N})$, fruit skin color $\left(\mathrm{L}^{*}, \mathrm{a}^{*}, \mathrm{~b}^{*}, \mathrm{C}^{*}, \mathrm{~h}^{\circ}\right)$, soluble solid content (\%), titratable acidity (mg.mL $\left.\mathrm{mL}^{-1}\right)$, respiration rate $\left(\mathrm{mL} \mathrm{CO} \mathrm{Kg}^{-1} \mathrm{~h}^{-1}\right)$ and sensory analysis were measured at the harvest time. All doses of putrescine treatments gave better results than control samples. Generally, the doses of 2.5 and $5 \mathrm{mM}$ putrescine positively affected the quality parameters such as fruit weight, flesh firmness, chroma, hue and titratable acidity. According to the results, the pre-harvest treatment of $2.5 \mathrm{mM}$ putrescine can be tool for improving the quality of sweet cherry at harvest.

Keywords: Poliamines, Quality, Prunus avium L., Pre-harvest treatment

\section{Giriş}

2016 yılı verilerine göre dünya kiraz üretiminin (2.317.956 ton) yaklaşık \% 26'sını üreten Türkiye, (599.650) dünya kiraz üretiminde ilk sırada yer almaktadır (FAOSTAT, 2018). Türkiye 547.285 tonluk Dünya kiraz ihracatının da yaklașık \% 14.58'ini (79.789 ton) Türkiye tek bașına gerçekleștirmektedir. Dünyada ve Türkiye'de geniș bir yayılım alanına sahip olan kiraz, Türkiye için ihracat olanakları ve ekonomik değeri yüksek olan meyve türlerinden biri haline gelmiştir. Ayrıca kirazların taze tüketiminin fazla ve sevilerek yenilen bir meyve olması da diş 
pazarlarda talebin artmasına neden olmuştur (Küden ve Sırış, 2001). Türkiye'de meyve kalitesi ile ön plana çıkmış olan "0900 Ziraat” kiraz çeşidi genellikle dış satım için üretilmekte ve Türkiye toplam kiraz üretiminin de büyük çoğunluğunu oluşturmaktadır (Akbulut ve Özcan, 2005; Demiral ve Ülger, 2008; Demirtaş ve Sarısu 2011). Ayrıca bu çeşidin meyvelerinin iri ve raf ömrünün uzun olması ile taşımadepolamaya dayanıklılığı bu çeşidin ihracatta en fazla aranan çeşit olmasına neden olmuştur. Türkiye dış satımı ve üretimde söz sahibi bu çeșidin, derim zamanındaki meyve kalitesinin de arttırılması önem kazanmaktadır. Ülkemizde ihracat için üretilen yaş meyve-sebzelerde kalite kayıpları hala çok yüksek (\%25-30) ve bu kalite kayıplarının daha çok derim öncesinde özellikle de derim sırasında meydana geldiği bilinmektedir (Ağar, 2002; Emre ve ark., 2008). Bu sebeplerden dolayı özellikle ihracata konu olan tür ve çeşitlerde derim öncesi ve derim sırasında kalitenin korunması ve iyileştirilmesi gerekmektedir. Kirazlarda, derim sırasında meyve iriliği, meyve kabuk rengi ve tat en önemli kalite parametreleri arasında yer almaktadır (Bolsu ve Akça, 2011). Meyve kalitesini iyileştirmek için birçok meyve-sebze türünde olduğu gibi kirazlarda da bitki büyüme düzenleyicileri kullanılmaktadır (Onursal ve ark., 2013). Son yıllarda kalitenin korunması ya da iyileştirilmesi amacı ile derim öncesi aminoetoksivinilglisin (AVG), poliaminler, salisilik asit ve metil jasmonat gibi bazı bitki büyüme düzenleyicileri kullanılmış ve olumlu sonuçlar elde edilmiştir (Khan and Singh, 2010; Onursal ve ark., 2013; Öztürk ve ark., 2013; Öztürk et al., 2017). Kalitenin korunması ya da iyileștirilmesi için kullanılan maddelerden birisi olan poliaminler (PA) tüm canlı organizmalarda bulunabilen, düşük molekül ağırlıklı bir aminoasit türevidir. PA'lar alifatik, aromatik ve heterosiklik olmak üzere üç grupturlar. Bitkilerde önemli fonksiyonu olan putresin, kadaverin, spermidin ve spermin olmak üzere alifatik PA'ların 4 tipi bulunmaktadır (Liu et al., 2000). Bunlardan putresin (PUT) genellikle en yüksek oranda bulunanıdır (Bal, 2012). Poliaminlerin, meyve olgunlaşması-yaşlanmasını geciktirdiği (Khan et al., 2007) , meyve eti yumuşamasını yavaşlattığı (Jhlegar et al., 2012), meyvenin dalda tutunma süresini, verim, meyve kabuk rengi ve kaliteyi (Malik and Singh, 2006), meyve tutumunu, meyve iriliğini ve derim sonrası kaliteyi de etkilediği (Bregoli et al., 2002; Malik and Singh, 2006) bildirilmiștir. $\mathrm{Bu}$ nedenle bu çalıșma ile ülkemiz kiraz üretimi ve ihracatında önemli rol oynayan 0900 Ziraat kiraz çeşidinde derim öncesi putresin uygu- lamalarının derim anındaki meyve kalitesi üzerine etkilerinin belirlenmesi amaçlanmıştır.

\section{Materyal ve Yöntem}

\section{Meyve materyali ve uygulamalar}

Denemede meyve materyali olarak kullanılan "0900 Ziraat" kiraz çeşidi (Gisela 5 anacı üzerine aşılı 7 yaşlı) Isparta'nın Uluborlu ilçesinde bir üretici bahçesinden temin edilmiştir. Bu kiraz çeşidi iri meyveli, meyve rengi parlak kırmızı ve meyve eti sert dokulu olan bir çeşittir (Akgül ve ark., 2005). Derim öncesi uygulamaları için ağaçlara sprey şeklinde tahmini ticari derim tarihinden 3 hafta önce 0 (kontrol), 2.5, 5 ve $7.5 \mathrm{mM}$ konsantrasyonlarında putresin (PUT) + $\% 0.01$ oranında yayıcı yapıştırıcı (Tween-20) ilave edilerek yapılmıştır. Kontrol ağaçlarına ise sadece saf su + yayıcı yapıştırıcı uygulanmıştır. Deneme tesadüf blokları deneme desenine göre 3 tekerrürlü (her tekerrürde 1 ağaç) olarak planlanmıştır. Kirazların derimi, bu çeşide özgü SÇKM, renk ve iriliğe ulaştığı zamanda yapılmıştır.

\section{Pomolojik analizler}

Çalışmada ortalama meyve ağırlığı (g), meyve eti ağırlığı (g) ve çekirdek ağırlığı (g), 0.01 g hassasiyetli teraziyle tartılarak belirlenmiştir. Ortalama meyve eni (mm) ve meyve boyu (mm) 0.01 mm'ye duyarlı dijital kumpas yardımıyla ölçülmüştür. Bu ölçümler için tekerrürde 30 adet meyve kullanılmıştır. Meyve eti sertliği ölçümleri, kirazların ekvatoral çevresi boyunca iki ayrı yerden yapılmıştır. Her tekerrürde 20 adet meyve kullanılarak Lloyd Marka LF Plus (Ametek, U.K.) Model tekstür cihazı ile meyve eti sertliği saptanmıştır. 50 N'luk load cell ile 100 $\mathrm{mm} / \mathrm{dk}$ değişmez hızda, $3 \mathrm{~mm}$ çapındaki (Neven and Drake, 2000) silindirik uç meyveye batırılmış ve elde edilen maksimum kuvvet Newton (N) cinsinden meyve eti sertliği olarak değerlendirilmiștir. Meyvelerin suyu katı meyve sıkacağı yardımıyla çıkartıldıktan sonra suda çözünebilir kuru madde miktarı (SÇKM) dijital el refraktometresi (Atago Pocket PAL1) ile ölçülmüş ve sonuçlar \% olarak belirlenmiştir. Titre edilebilir asit (TEA) miktarı, çıkartılan meyve suyundan $10 \mathrm{~mL}$ alınmış 0.1 N'lik sodyum hidroksit $(\mathrm{NaOH})$ ile $\mathrm{pH}$ değeri 8.1 oluncaya kadar $\mathrm{pH}$ metre (WTW Inolab) kullanılarak titre edilerek belirlenmiştir. Sonuçlar harcanan $\mathrm{NaOH}$ miktarı üzerinden malik asit cinsinden $\mathrm{mg} \mathrm{mL}^{-1}$ olarak hesaplanmıştır. Meyve kabuk rengi, renk cihazı (CR-300 Minolta) kullanılarak CIEL*a*b* cinsinden ölçülmüş, bu verilerden kroma $\left(\mathrm{C}^{*}\right)$ ve hue açısı $\left(\mathrm{h}^{\circ}\right)$ değerleri McGuire (1992)'e göre aşağıdaki formüllerle hesaplanmıştir. 


$$
\mathrm{h}^{\circ}=\tan ^{-1}\left(\mathrm{~b}^{*} / \mathrm{a}^{*}\right) \quad \mathrm{C}^{*}=\left[\left(\mathrm{a}^{*}\right)^{2}+\left(\mathrm{b}^{*}\right)^{2}\right]^{1 / 2}
$$

Solunum hızı ölçümleri için kirazlar $0.5 \mathrm{~L}$ hacmindeki gaz sızdırmaz kavanozlarda yaklaşık 180-200 gram olacak şekilde tartılmış ve ağzı sıkıca kapatılmıştır. Oda koşullarında $\left(20 \pm 1{ }^{\circ} \mathrm{C}\right) 2$ saat bekletildikten sonra kavanozlardan gaz kaçırmaz plastik şırınga ile 15-20 mL hava alınarak doğrudan gaz kromatografisine (Agilent, GC-6890N) enjekte edilmiştir. Sonuçlar mL.CO2. $\mathrm{kg}^{-1} \mathrm{~s}^{-1}$ olarak verilmiştir.

Denemede her tekerrürde 1 ağaç kullanılmış ve deneme tesadüf blokları şeklinde kurulmuştur. Elde edilen bulgular JMP paket programında faktöriyel düzende varyans analizi tekniği ile analiz edilmiş ve uygulamalar arasındaki farklılıkları belirlemek için LSD çoklu karşılaştırma testi kullanılmıştır.

\section{Sonuçlar ve Tartışma}

Putresin uygulamalarının meyve ağırlığı, meyve eti ağırlığı ve çekirdek ağırlığı üzerine etkileri Çizelge 1 'de sunulmuştur. Çalışmada ortalama meyve ağırlığı $8.84 \mathrm{~g}$ (kontrol) ile $10.12 \mathrm{~g}$ (2.5 mM PUT) arasında, meyve eti ağırlığı $7.86 \mathrm{~g}$ (kontrol) ile $9.23 \mathrm{~g}$ (2.5 mM PUT) arasında ve çekirdek ağırlığı da 0.58 (kontrol) ile 0.63 g (5 mM P PUT) arasında değișmiştir. Uygulamaların meyve ağırlığı ve meyve eti ağırlığı üzerine etkileri önemli olurken ( $p<0.05$ ), çekirdek ağırlığl üzerine etkisi önemsiz olmuştur ( $\mathrm{p}<0.05)$. Bütün PUT dozları meyve ağırlığını kontrol grubuna kıyasla artırmıştır. En yüksek meyve ağırlığı 10.12 g ile 2.5 mM PUT dozundan elde edilmiş bunu sırasıyla 7.5 $\mathrm{mM}, 5 \mathrm{mM}$ ve kontrol uygulamaları takip etmiştir. Ortalama meyve eti ağırlığında da, meyve ağırlığına benzer sonuçlar elde edilmiş ve en yüksek meyve eti ağırlığı 2.5 mM (9.23 g) dozundan elde edilirken en düşük meyve eti ağırlığı kontrol (7.86 g) uygulamasından elde edilmiştir. Çalışmada PUT uygulamalarının meyve ağırlığı ve meyve eti üzerine bariz etkileri olmuştur. Bunu da hücre büyümesi üzerine etki ederek yapmış olabileceği düşünülmektedir. Nitekim çalışmalarda, poliaminlerin hücre büyümesi üzerine olumlu etkileri olduğu rapor edilmiştir (Hussain et al., 2011; Algül ve ark., 2016). Uygulama meyvelerinin ortalama çekirdek ağırlığı, kontrole göre nispeten daha fazla olsa da önemli bir farklılık bulunamamıştır. PUT uygulamasının kirazlardaki çekirdek ağırlı̆̆ına önemli bir etki etmemesinin nedeninin, çekirdek gelişiminin PUT uygulamasından (derimden 21 gün önce) önce tamamlanmış olabileceği olarak düşünülmektedir.
Çizelge 1. Putresin uygulamalarının meyve ağırlığı (g), meyve eti ağırlığı (g) ve çekirdek ağırlığı (g) üzerine etkileri

\begin{tabular}{cccc}
\hline Uygulamalar & Meyve ağırlı̆̆ & Meyve eti ağ. & Çekirdek ağ. \\
\hline Kontrol & $8.84 \pm 0.27 \mathrm{~b}^{*}$ & $7.86 \pm 0.26 \mathrm{~b}$ & $0.58 \pm 0.01$ öd \\
$2.5 \mathrm{mM}$ & $10.12 \pm 0.24 \mathrm{a}$ & $9.23 \pm 0.25 \mathrm{a}$ & $0.61 \pm 0.02$ \\
$5 \mathrm{mM}$ & $9.06 \pm 0.38 \mathrm{ab}$ & $8.77 \pm 0.37 \mathrm{ab}$ & $0.63 \pm 0.01$ \\
$7.5 \mathrm{mM}$ & $9.68 \pm 0.41 \mathrm{ab}$ & $8.22 \pm 0.41 \mathrm{~b}$ & $0.62 \pm 0.03$
\end{tabular}

Farklı harflerle gösterilen ortalamalar arasındaki farklılıklar istatistik olarak önemlidir ( $p<0.05)$. öd: önemli değil. Ortalama \pm standart hata

Putresin uygulamalarının kirazların meyve boyu üzerine etkileri önemli bulunurken meyve eni üzerine etkileri önemsiz bulunmuştur ( $\mathrm{p}<0.05)$. Kirazların meyve eni $(\mathrm{mm})$ ve meyve boyu $(\mathrm{mm})$ üzerine uygulamaların etkisi Çizelge 2'de verilmiştir.

Çizelge 2. Putresin uygulamalarının kirazların meyve eni $(\mathrm{mm})$ ve boyu $(\mathrm{mm})$ üzerine etkileri

\begin{tabular}{ccc}
\hline Uygulamalar & Meyve eni & Meyve boyu \\
\hline Kontrol & $25.99 \pm 0.60$ öd & $24.35 \pm 0.25 \mathrm{~b}$ \\
$2.5 \mathrm{mM}$ & $26.62 \pm 0.30$ & $25.72 \pm 0.20 \mathrm{a}$ \\
$5 \mathrm{mM}$ & $26.25 \pm 0.43$ & $24.73 \pm 0.34 \mathrm{~b}$ \\
$7.5 \mathrm{mM}$ & $26.60 \pm 0.46$ & $24.18 \pm 0.31 \mathrm{~b}$ \\
\hline
\end{tabular}

Farklı harflerle gösterilen ortalamalar arasındaki farkllıklar istatistik olarak önemlidir ( $\mathrm{p}<0.05)$. öd: önemli değil. Ortalama \pm standart hata

Derim zamanında meyve boyu bakımından en yüksek değer (25.72 mm) $2.5 \mathrm{mM}$ PUT dozundan elde edilmiştir. Çalışmada ortalama en ve boy değerleri incelendiğinde, kirazlarda önemli kalite parametrelerinden biri olan iriliğin PUT uygulamaları ile kontrol grubuna göre arttığı görülmektedir. $\mathrm{Bu}$ artışın putresinin hücre uzaması üzerine olan etkilerinden kaynaklandığı düşünülmektedir. Benzer şekilde Kaur- Sawhney et al. (1980), Yatin (2002) ve Çavuşoğlu ve Kabar (2007) çalışmalarında, bitkilerde ve hayvanlarda yaygin olarak bulunan poliaminlerden olan putresin, spermidin ve sperminin, hücrelerin gelişmesinde önemli katkı sağladıklarını bildirmişlerdir.

Kirazlarda, antosiyanin içeriğine bağlı olarak değișen meyve kabuk rengi, önemli derim ve kalite kriterlerinden biridir (Eroğul, 2016). Putresin uygulamalarının kirazların meyve rengi $\left(L^{*}, a^{*}, b^{*}, C^{*}\right.$ ve $\left.h^{\circ}\right)$ üzerine etkileri Çizelge 3'te sunulmuştur. Parlaklığı ifade eden $L^{*}$ değeri en yüksek kontrol grubundan elde edilmiş, bunu sırasıyla $2.5 \mathrm{mM}, 7.5 \mathrm{mM}$ ve $5 \mathrm{mM}$ PUT dozları takip etmiştir. $L^{*}$ değerinin kontrol grubunda kısmen yüksek olması bu gruptaki meyvelerin kırmızı renklerinin doygunluğunun az olmasıyla ilişkilendirebiliriz. Çalışmadaki kırmızılığı ifade eden a* renk değerleri de bu durumu destekler niteliktedir. 
Kroma (C*) değeri rengin doygunluğunu (canlılığı)matlığını ifade etmektedir $(0=$ mat, $60=$ doygun $)$ (McGuire, 1992). Uygulama meyvelerinin $C^{*}$ değerleri kontrol grubuna göre önemli ölçüde yüksek çıkmiştır. Bu da PUT uygulanan meyvelerin daha parlak-canlı olduğunun bir göstergesidir. Hue açısı $\left(\mathrm{h}^{\circ}\right)$ değerleri incelendiğinde en yüksek (26.02) $\mathrm{h}^{\circ}$ değeri 2.5 mM PUT dozundan elde edilirken, en düşük değer (18.32) kontrol grubundan elde edilmiştir. Hue açısı bir renk dairesi olup kırmızı-mor renkler için $0^{\circ}$ - 360 ${ }^{\circ}$ arasında açı değerini almaktadır (McGuire, 1992). Kırmızı-mor kabuk rengine sahip ürünlerde, hue açı değerinin 0'a yaklaşması, meyvede kırmızı rengin koyulaştığının bir göstergesidir (Erbaş ve Koyuncu, 2016). Bu bilgiler doğrultusunda, elde edilen renk verileri değerlendirildiğinde, uygulama meyvelerinin daha canlı ( $\mathrm{C}^{*}$ değeri yüksek) ve daha kırmızı ( $\mathrm{a}^{*}$ değeri yüksek) renge sahip olduğunu, kontrol meyvelerinin ise kısmen koyu ancak daha az doygun kırmızı renge sahip olduğunu söyleyebiliriz. Öte yandan bazı meyve türleri (kiraz, kayısı, çilek, mango ve papaya) ile yapılan çalışmalarda da, poliaminlerin klorofil parçalanmasını yavaşlatarak renk gelişimini geciktirebileceği rapor edilmiștir (Purwoko et al., 1998; Martinez-Romero et al., 2002; Valero et al., 2002; Khosroshahi et al., 2007; Bal, 2012). Kirazlarda, tüketicilerinin aradığı temel kalite parametreleri irilik, renk, sertlik ve suda çözünür kuru madde miktarıdır (Diaz-Mula et al., 2009; Valero and Serrano, 2010; Serradilla et al., 2012). Çalışmada PUT uygulamalarının, kirazların suda çözünür kuru madde miktarı (\%), titre edilebilir asitlik (mg. $\left.\mathrm{mL}^{-1}\right)$, solunum hızı (mL.CO $\left.2 \cdot \mathrm{kg}^{-1} \mathrm{~s}^{-1}\right)$ ve meyve eti sertliği (N) üzerine etkileri Çizelge 4'te gösterilmiştir. Uygulama meyvelerinin SÇKM miktarı kontrol grubuna göre nispeten daha düşük olmuştur. En yüksek SÇKM değeri kontrol grubunda, en düşük ise $5 \mathrm{mM}$ PUT dozundan elde edilmiştir. PUT uygulanan kirazlarda SÇKM miktarını düşük olmasını, putresinin olgunlaşma ve yaşlanmayla ilgili olan fizyolojik olayları geciktirmesi olarak yorumlanabilir.

Bazı ürünlerde olgunluğun ilerlemesi ile genellikle asitlik miktarının nispeten azaldığı bilinmektedir (Karaçalı, 2006). Çalışmada da en düşük TEA değeri kontrol grubunda ölçülürken, en yüksek değerde 2.5 mM PUT uygulamasında ölçülmüştür. Kontrol uygulamasında asitlik değerinin düşük olmasını olgunlaşmanın ilerlemiş olmasına bağlı olarak kirazların bünyesindeki bazı asitlerin azalmasına dayandırılabilir (Khosroshahi et al., 2008). Uygulama meyvelerinde de asitliğin yüksek kalmasını PUT uygulamalarının kirazların solunum hızını yavaşlatarak olgunlaşma-yaşlanma metabolizmasını da yavaşlatması şeklinde açılkayabiliriz. TEA miktarında elde edilen bulgular solunum hızı (Çizelge 4) verileri ile de desteklenmektedir.

Derim öncesi PUT uygulanan kirazların solunum hızı değerleri, kontrol grubuna göre önemli ölçüde azalmiştır. Kontrol grubunda 8.050 mL.CO $2 . \mathrm{kg}^{-1} \mathrm{~s}^{-1}$ olarak ölçülen solunum hızı değeri, $7.5 \mathrm{mM}$ dozunda 6.200 mL.CO $2 . \mathrm{kg}^{-1} \mathrm{~s}^{-1}, 5 \mathrm{mM}$ dozunda 5.669 mL.CO $2 . \mathrm{kg}^{-1} \mathrm{~s}^{-1}$ ve $2.5 \mathrm{mM}$ dozunda da $5.261 \mathrm{~mL} \cdot \mathrm{CO}_{2} \cdot \mathrm{kg}^{-1} \mathrm{~s}^{-1}$ olarak ölçülmüştür.

Çizelge 3. Putresin uygulamalarının kirazların meyve kabuk rengi üzerine etkileri

\begin{tabular}{ccccc}
\hline Uygulamalar & $\mathrm{L}^{*}$ & $\mathrm{a}^{*}$ & $\mathrm{~b}^{*}$ & Kroma $\left(\mathrm{C}^{*}\right)$ \\
\hline Kontrol & $32.45 \pm 2.23$ od & $16.26 \pm 1.14 \mathrm{~b}$ & $5.27 \pm 0.56 \mathrm{c}$ & $17.22 \pm 1.12 \mathrm{~b}$ \\
$2.5 \mathrm{mM}$ & $30.94 \pm 3.02$ & $23.95 \pm 0.82 \mathrm{a}$ & $11.64 \pm 1.04 \mathrm{a}$ & $26.97 \pm 0.58 \mathrm{a}$ \\
$5 \mathrm{mM}$ & $26.72 \pm 0.49$ & $23.51 \pm 0.59 \mathrm{a}$ & $7.91 \pm 0.42 \mathrm{~b}$ & $24.82 \pm 0.68 \mathrm{a}$ \\
$7.5 \mathrm{mM}$ & $27.73 \pm 0.70$ & $23.68 \pm 1.14 \mathrm{a}$ & $8.23 \pm 0.68 \mathrm{~b}$ & $25.02 \pm 2.00 \mathrm{~b}$ \\
\hline
\end{tabular}

Farklı harflerle gösterilen ortalamalar arasındaki farklılıklar istatistik olarak önemlidir $(\mathrm{p}<0.05)$. öd: önemli değil. Ortalama \pm standart hata

Çizelge 4. Putresin uygulamalarının, kirazların suda çözünür kuru madde miktarı (\%), titreedilebilir asitlik (mg.mL $\left.{ }^{-1}\right)$, solunum hızı (mL.CO $\left.2 . \mathrm{kg}^{-1} \mathrm{~S}^{-1}\right)$ ve meyve sertliği $(\mathrm{N})$ üzerine etkileri

\begin{tabular}{cccc}
\hline Uygulamalar & SÇKM & TEA & Solunum hizl \\
\hline Kontrol & $15.53 \pm 0.03 \mathrm{a}$ & $1.39 \pm 0.06 \mathrm{c}$ & $8.050 \pm 0.33 \mathrm{a}$ \\
$2.5 \mathrm{mM}$ & $14.37 \pm 0.23 \mathrm{~b}$ & $2.02 \pm 0.02 \mathrm{a}$ & $5.261 \pm 0.21 \mathrm{~b}$ \\
$5 \mathrm{mM}$ & $14.17 \pm 0.17 \mathrm{~b}$ & $1.86 \pm 0.07 \mathrm{ab}$ & $5.669 \pm 0.11 \mathrm{~b}$ \\
$7.5 \mathrm{mM}$ & $15.07 \pm 0.07 \mathrm{a}$ & $1.74 \pm 0.03 \mathrm{~b}$ & $6.200 \pm 0.53 \mathrm{~b}$ \\
\hline
\end{tabular}

Farklı harflerle gösterilen ortalamalar arasındaki farklılıklar istatistik olarak önemlidir ( $<<0.05)$. Ortalama \pm standart hata

Putresin uygulamaları doza bağlı olmaksızın derim anındaki solunum hızını düşürmüştür. Bununla birlikte solunum hızının baskı altına alınması bakımın- dan düşük doz olarak uygulanan $2.5 \mathrm{mM}$ dozu daha etkili olmuştur. Martinez-Romero et al. (2002), kaylsılarda yaptıkları çalışmalarında putresin uygulama- 
sının kayısıların solunum hızını uygulama yapılmayan meyvelere oranla azalttığını bildirmişlerdir. Meyve eti sertliği, kirazların depolanabilme süresini ve pazarlanabilme yeteneğini etkileyen önemli bir faktördür (Esti et al., 2002). Çalış̧mada derim anında en düşük sertlik değeri kontrol grubunda elde edilmiş olup, en yüksek değer ile 2.5 mM PUT uygulamasindan elde edilmiştir. PUT dozunun artışına paralel olarak sertlik değerleri de azalmıştır. En yüksek PUT dozunda $(7.5 \mathrm{mM})$ en düşük sertlik değeri, en düşük dozda da $(2.5 \mathrm{mM})$ en yüksek sertlik değeri elde edilmiştir. Bu durum meyve türüne göre uygun doz seçiminin önemli olduğunu göstermektedir. Meyvelerin olgunlaşması ilerledikçe meyve sertliği de azalmaktadır. Poliaminlerin bahçe ürünlerinde, olgunlaşma-yaşlanma fizyolojisini geciktirerek (Serrano et al., 2003) ve hücrede yapısal bütünlüğü olumlu yönde etkileyerek meyve sertliğini koruduğu bildirilmiştir (Messiaen et al., 1997; Valero et al., 1998) . Bu bilgiler çalışmadan elde edilen sertlik değerlerini doğrulamaktadır. Derim öncesi PUT uygulamalarının kirazların dış görünüș ve tat üzerine etkileri istatistik olarak önemli olmamıștır (veriler sunulmamıștır). Ancak istatistik olarak fark bulunmamasına rağmen, derim anında uygulama yapılan kirazlar kontrol grubuna oranla hem tat hem de dış görünüș bakımından daha iyi sonuçlar vermiştir. Kirazların derim anındaki meyve kalitesine, putresin uygulamasının etkilerinin incelendiği bu çalışmada, derim öncesi farklı dozlarda PUT uygulamalarının kirazlarda meyve kalitesini olumlu yönde etkilediği bulunmuştur. Ayrıca çalışmada incelenen kalite parametreleri açısından düşünüldüğünde, özellikle $2.5 \mathrm{mM}$ PUT dozunun, "0900 Ziraat" kiraz çeşidinin derim sırasındaki meyve kalitesinin iyileştirilmesi bakımından daha iyi sonuçlar verdiği söylenebilir.

\section{Kaynaklar}

Ağar, İ.T., 2002. Bahçe ürünlerini AB standartlarına ulaştırma için derim sonrasında alınması gereken önlemler. II. Bahçe Ürünlerinde Muhafaza ve Pazarlama Sempozyumu, Çanakkale , 1-13.

Akbulut, M., Özcan, M., 2005. 0900 Ziraat kiraz çeşidinde hasat sonrası farklı ambalaj uygulamalarının ürün ve kalite kayıpları üzerine etkilerinin araştırılması. III. Bahçe Ürünlerinde Muhafaza ve Pazarlama Sempozyumu (6-9 Eylül, Hatay).

Akgül, H., Dolunay, E. M., Özongun, Ş., Özyiğit, S., Atasay, A., Demirtaş, İ., Pektaş, M., Öztürk, G., Karamürsel, Ö. F., Sesli, Y., Göktaş, A., Gür, İ., Sarısu, H. C., Karaarslan, Z., 2005. Meyve Çeşit Kataloğu. Eğirdir Bahçe Kültürleri Araş. Ens. No: 12. Isparta, 360 s.
Algül, B. E., Tekintaş, F. E., Dalkılıç, G. G., 2016. Bitki büyüme düzenleyicilerinin kullanımı ve içsel hormonların biyosentezini arttırıcı uygulamalar. Adnan Menderes Üniv Z.F. Dergisi, 13 (2): 87-95.

Bal, E., 2012. Hasat sonrası putresin ve salisilik asit uygulamalarının kirazın soğukta muhafazası üzerine etkisi. Süleyman Demirel Üniversitesi Ziraat Fakültesi Dergisi, 7 (2): 23-31.

Bolsu, A., Akça, Y., 2011. Mahlep anacı üzerine aşılı 5 kiraz çeșidinin bazı morfolojik özellikleri ile meyve kalite özelliklerinin belirlenmesi. Yüzüncü Yıl Üniversitesi Tarım Bilimleri Dergisi, 21 (3): 152-157.

Bregoli, A. M., Scaramagli, S., Costa, G., Sabatini, E., Ziosi, V., Biondi, S., Torrigiani, P., 2002. Peach (Prunus persica) fruit ripening: Aminoethoxyvinylglycine (AVG) and exogenous polyamines affect ethylene emission and flesh firmness. Physiologia Plantarum, 114 (3): 472-481.

Çavușoğlu, K., Kabar, K., 2007. Turp tohumlarının tuzlu koşullar altındaki çimlenme ve fide büyümesine bazı bitki büyüme düzenleyicisi ön uygulamalarının etkileri. Dumlupınar Üniversitesi Fen Bilimleri Enstitüsü Dergisi, 14: 27-36.

Demiral, S., Ülger, S., 2008. Gisela 5 kiraz anacının doku kültürü ile çoğaltılması üzerine bir araștırma. Akdeniz Üniversitesi Z.F. Dergisi, 21 (1): 117-121.

Demirtaş, İ., Sarısu, H. C., 2011. Kiraz Yetiştiriciliği. Eğirdir Meyvecilik Araștırma İstasyonu Müdürlüğü Yayınları, Yayın No:11, 12 s, Isparta.

Diaz-Mula, H. M., Castillo, S., Martínez-Romero, D., Valero, D., Zapata, P. J., Guillén, F., Serrano, M., 2009. Sensory, nutritive and functional properties of sweet cherry as affected by cultivar and ripening stage. Food Sci Tech International, 15 (6): 535-543.

Emre, M., Karamürsel, D., Kaçal, E., Öztürk, F. P., Emre, A. R., Karamürsel, Ö. F., Öztürk, G., 2008. Jerseymac yazlık elma çeşidinde derim öncesi ve derim sırasında meydana gelen kayıpların değerlendirilmesi. Bahçe Ürünlerinde IV. Muhafaza ve Pazarlama Sempozyumu, Antalya, 138-144.

Erbaş, D., Koyuncu, M. A., 2016. 1-metilsiklopropen uygulamasının Angeleno erik çeșidinin depolanma süresi ve kalitesi üzerine etkileri. Ege Üniversitesi Ziraat Fakültesi Dergisi, 53 (1): 43-50.

Eroğul, D., 2016. İzmir İlinde yetiştirilen bazı önemli kiraz çeşitlerinin fiziksel ve kimyasal özelliklerinin belirlenmesi. Yüzüncü Yıl Üniversitesi Tarım Bilimleri Dergisi, 26 (4): 579-585.

Esti, M., Cinquanta, L., Sinesio, F., Moneta, E., Di Matteo, M., 2002. Physicochemical and sensory fruit characteristics of two sweet cherry cultivars after cool storage. Food Chemistry, 76 (4): 399-405. 
Food and Agriculture Organization of the United Nations (FAO). 2018. FAOSTAT. http://faostat.fao.org/ Accessed date: July, 2018.

Hussain, S. S., Ali, M., Ahmad, M., Siddique, K. H. M., 2011. Polyamines: natural and engineered abiotic and biotic stress tolerance in plants. Biotechnology Advances, 29: 300-311.

Jhalegar, Md. J., Sharma, R. R., Pal, R. K., Rana, V., 2012. Effect of postharvest treatments with polyamines on physiological and biochemical attributes of kiwifruit cv. Allison. Fruits, 67 (1): 13-22.

Karaçalı, İ., 2006. Bahçe Ürünlerinin Muhafaza ve Pazarlanması. Ege Üniversitesi Ziraat Fakültesi Yayınları No: 494, İzmir, $481 \mathrm{~s}$.

Kaur-Sawhney, R., Flores, H.E., Galston, A.W., 1980. Polyamine-induced DNA synthesis and mitosis in oat leaf protoplasts. Plant Physiol, 65(2): 368-37.

Khan, A. S., Singh, Z., 2010. Pre-harvest application of putrescine influences Japanese plum fruit ripening and quality. Food Science and Technology International, 16 (1): 53-64.

Khan, A.S., Singh, Z., Abbasi, N.A., 2007. Pre-storage putrescine application suppresses ethylene biosynthesis and retards fruit softening during low temperature storage in 'Angelino' plum. Postharvest Biology and Technology, 46 (1): 36-46.

Khosroshahi, M. R. Z., Esna-Ashari, M., Fattahi, M., 2008. Effect of exogenous putrescine on postharvest life of sweet cherry (Prunus avium) fruit, cultivar "Surati-e Hamedan". Journal of Applied Horticulture, 10 (2): 154-157.

Kuden, A., Sırış, Ö., 2001. Ülkemiz yayla koşullarında uygun yeni kiraz çeşitlerinin meyve verimi ve kalitesi üzerinde çalıșmalar. Atatürk Bahçe Kültürleri Merkez Araştırma Enstitüsü, I. Sert Çekirdekli Meyveler Sempozyumu Bildirileri, 103-113.

Liu, K., Fu, H., Bei, Q., Luan, S., 2000. Inward potassium channel in guard cells as a target for polyamine regulation of stomatal movements. Plant Physiology, 124 (3): 1315-1326.

Malik, A. U., Singh, Z., 2006. Improved fruit retention, yield and fruit quality in mango with exogenous application of polyamines. Scientia Horticulturae, 110 (2): 167-174.

Martinez-Romero, D., Serrano, M., Carbonell, A., Burgos, L., Riquelme, F., Valero, D., 2002. Effects of postharvest putrescine treatment on extending shelf life and reducing mechanical damage in apricot. Journal of Food Science, 67 (5): 1706-1712.

McGuire, R. G., 1992. Reporting of objective color measurements. HortScience, 27 (12): 1254-1255.

Messiaen, J., Cambier, P., Van Cutsem, P., 1997. Polyamines and pectins. Plant Physiology, 113 (2): 387-395.

Onursal, C. E., Çalhan, Ö., Eren, İ., Çetinbaş, M., Butar, S., Demirtaş, İ., 2013. Derim öncesi aminoetoksivinilglisin (AVG) uygulamalarının 0900 Ziraat kiraz çeşidinin soğukta muhafazası ve raf ömrü kalitesi. Tarım Bilimleri Araştırma Dergisi, 6 (1): 91-96.

Öztürk, B., Küçüker, E., Saraçoğlu, O., Yıldız, K., Özkan, Y., 2013 . 0900 Ziraat kiraz çeşidinin meyve kalitesi ve biyokimyasal içeriği üzerine büyümeyi düzenleyici maddelerin etkisi. Tekirdağ Ziraat Fakültesi Dergisi, 10 (3): 82-89.

Öztürk, B., Yıldız, K., Uzun, S., Öztürk, A., 2017. Effects of pre-harvest AVG treatments on fruit quality of Jonagold apple cultivar throughout cold storage. International J Agric Wildlife Science, 3 (1): 1-5.

Purwoko, B. .S., Kesmayanti, N., Susanto, S., Zein Nasution, M., 1998. Effect of polyamines on quality changes in papaya and mango fruits. Acta Hortic, 464: 510.

Serradilla, M. J., Martín, A., Ruiz-Moyano, S., Hernández, A., López-Corrales, M., Guía Córdoba, M., 2012. Physicochemical and sensorial characterisation of four sweet cherry cultivars grown in Jerte Valley (Spain). Food Chemistry, 133 (4): 1551-1559.

Serrano, M., Martinez-Romero, D., Guillen, F., Valero, D., 2003. Effects of exogenous putrescine on improving shelf life of four plum cultivars. Postharvest Biology and Tech, 30 (3): 259-271.

Valero, D., Martinez-Romero, D., Serrano, M., 2002. The role of polyamines in the improvement of the shelf life of fruit. Trends in Food Science and Technology, 13 (6): 228-234

Valero, D., Martínez-Romero, D., Serrano, M., Riquelme, F., 1998. Influence of postharvest treatment with putrescine and calcium on endogenous polyamines, firmness, and abscisic acid in lemon (Citrus lemon L. Burm cv. Verna). Journal of Agricultural and Food Chemistry, 46 (6): 2102-2109.

Valero, D., Serrano, M., 2010. Postharvest Biology and Technology for Pre-serving Fruit Quality. CRCTaylor \& Francis, Boca Raton, FL, 288 pp.

Yatin, M., 2002. Polyamines in living organisms. Journal of Cell and Molecular Biology, 1: 57-67. 